\title{
Natural Chemical Composition of Commercial Fish Species: Characterisation of Pangasius, Wild and Farmed Turbot and Barramundi
}

\author{
Monika Manthey-Karl *, Ines Lehmann, Ute Ostermeyer and Ute Schröder \\ Department of Safety and Quality of Milk and Fish Products, Max Rubner-Institut, Federal Research Institute of \\ Nutrition and Food, Palmaille 9, 22767 Hamburg, Germany; Ines.Lehmann@mri.bund.de (I.L.); \\ Ute.Ostermeyer@mri.bund.de (U.O.); Ute.Schroeder@mri.bund.de (U.S.) \\ * Correspondence: Monika.Manthey@mri.bund.de; Tel.: +49-40-38905293; Fax: +49-40-38905262 \\ Academic Editor: Michael Jahncke \\ Received: 2 June 2016; Accepted: 10 August 2016; Published: 30 August 2016
}

\begin{abstract}
To comply with the relevant legal requirements and correct labelling, it is necessary for business operators and inspection authorities to know the natural characteristics of the raw material. This study gives a comprehensive overview of muscle flesh composition of farmed and wild Atlantic turbot (Scophthalmus maximus) and barramundi (Lates calcarifer) and of farmed pangasius (Pangasianodon hypophthalmus). The proximate composition, di- and triphosphates and citric acid values are presented in order to evaluate possible indicators for a hidden treatment during processing to fillets. All moisture contents were $\leq 80 \%$. Even for pangasius, protein values for deep skinned fillets of $\geq 18 \%$ were determined. Only small quantities of naturally occurring citric acid (up to $0.03 \mathrm{~g} \cdot \mathrm{kg}^{-1}$ ) were detectable. The lipid content was the most varying main component within the different species, ranging between $1.2 \%$ to $2.0 \%$ and $0.3 \%$ to $3.0 \%$ for farmed turbot and barramundi, respectively. Pangasius flesh had a mean lipid content of 7.8\%. Trimming and separation of the red layer reduced the lipid content of the commercially sold white-flesh fillets to $2.7 \%$ to $3.5 \%$. Fatty acids profiles, free amino acids, and minerals were analysed to show the nutritional quality of the aquaculture fish species and compared to wild turbot and barramundi. Despite some natural variation, these components can be considered as comparable.
\end{abstract}

Keywords: aquaculture; proximate composition; minerals; fatty acids; free amino acids; citric acid; phosphates; water content

\section{Introduction}

More and more fish are being raised on farms; globally it accounts almost for $50 \%$ of the fish consumed [1]. Like other goods, aquaculture products must pass through distribution channels in order to reach the consumer as the end-user. In Europe, improved logistics and effective intermediaries have shortened the chain so that imported fish are brought directly from the source by the wholesaler. Higher prized fish are often marketed fresh and whole, like Atlantic turbot (Scophthalmus maximus) from aquaculture plants in Chile or Spain. As its wild counterparts, this flatfish species is a relatively scarce "gourmet" fish. European aquaculture production of Atlantic turbot has grown steadily up to more than 12,000 $\mathrm{t}$ in 2012 [2] and extended worldwide to 77,000 $\mathrm{t}$ in 2013 [3]. Barramundi or giant perch, (Lates calcarifer) is indigenous to the waters of South East Asia and Northern Australia and tolerates a wide range of salinities which allows for cultivation in both, fresh and seawater $[4,5]$. It is a rather new species on the European market, whereas pangasius (Pangasianodon hypophthalmus), mainly imported from Vietnam, has been popular for several years. However, it has also been the subject of criticism because of very different qualities [6-8]. Both species are mostly provided frozen as fillets. Barramundi and Atlantic turbot rank among the species with high international reputations 
as fish with premium eating qualities, whereas pangasius belongs to the low cost products on the German market.

As a valuable source of protein, essential fatty acids, and micronutrients, fish is important for diversified and healthy diets. However, several publications and annual reports of federal investigation offices for food in Germany often note appreciable changes at the retail level, mainly resulting from too high water content $[6,9]$.

In order to verify the conformance with legislation and to comply with correct labelling requirements, it is important for business operators and inspection authorities to know the natural composition of the product. Consumers' growing reservations about chemical ingredients, such as phosphates, have led to an increasing number of products with "chem-free" labels. Therefore, the aim of this study was to analyse and to determine what differences (if any) exist between untreated raw muscle flesh of pangasius and wild and farmed turbot and barramundi for proximate composition, fatty acids, minerals, amino acids, citric acid, and phosphate concentrations.

\section{Materials and Methods}

\subsection{Sample Procurement}

All fish were delivered adequately cooled to the Max Rubner-Institut in Hamburg, Germany, where the chemical analyses were carried out. Raising conditions and transport were not assessed nor controlled in this study.

Turbot: Organised by a German wholesaler, whole fresh turbots were directly transferred from four different aquaculture plants within five days to the institute in polystyrene boxes in ice by air from Chile or by truck from Spain, respectively. Wild turbot was caught in the North-East Atlantic and delivered gutted via Lemvig, Denmark. Upon arrival, all specimens were individually weighed, filleted, and deep frozen.

Barramundi: Gutted plate size saltwater barramundi were bought directly from an Australian aquaculture company; fresh fillets of wild barramundi were purchased from an Australian seafood retail outlet. All samples were delivered frozen by air cargo. Frozen skinned fillets from farmed and wild barramundi were imported from Vietnam and obtained from a wholesaler.

Pangasius: Eviscerated headed fish, skin-on cutlets, and European Union (EU) organic certificated skinned fillets were imported frozen from Vietnam and obtained from a wholesaler.

All fish were stored in the same storage chamber, except those for the investigation of citric acid and condensed phosphates which were kept at $-80^{\circ} \mathrm{C}$. For chemical analysis, samples were thawed in a refrigerator overnight at $4{ }^{\circ} \mathrm{C}$. Barramundi fillets without skin were prepared from the Australian fish. In the case of whole pangasius, one fillet of each specimen was skinned without removing the red muscle layer, the other was deep skinned. Both were trimmed. From pangasius cutlets, only the white flesh was used.

The resulting samples (including drip loss, if any) were homogenized. Chemical tests of the homogenates were done in duplicate.

\subsection{Chemical Analyses}

\subsubsection{Proximate Composition, Total Volatile Basic Nitrogen (TVB-N) and $\mathrm{pH}$}

Percent moisture and ash content were determined by drying samples of approximately $5 \mathrm{~g}$ at $105^{\circ} \mathrm{C}$ for $12 \mathrm{~h}$ to a constant weight, followed by ashing at $550{ }^{\circ} \mathrm{C}$ [10].

Percent nitrogen was measured by modified Dumas method, using a LECO TruSpecN (LECO Instruments GmbH, Mönchengladbach, Germany). Percent protein was calculated by multiplying percent nitrogen by 6.25 [11]. Total lipids were extracted, using the method described by Smedes [12] with modification by Karl et al. [13] which included extraction of lipids from the homogenised sample with a mixture of isopropanol and cyclohexane. Percent salt $(\mathrm{NaCl})$ was obtained 
by potentiometric titration of an aqueous sample solution with $0.1 \mathrm{~N} \mathrm{AgNO}_{3}$ solution, applying the method of Karl et al. [14]. The total phosphorus content was estimated photometrically in the nitric acid extract of the ash, according to a modified official $\S 64$ LFGB German method to determine phosphorus in meat [15]. The colorimetric reaction was measured at $430 \mathrm{~nm}$. The $\mathrm{pH}$ value was determined in minced samples (homogenised with one part of deionised water). A perchloric acid extract of $20 \mathrm{~g}$ homogenised muscle flesh and $180 \mathrm{~mL} 6 \%(w / w)$ perchloric acid was used after filtration for the determination of TVB-N [16]. Certified reference materials were used as quality control for the accuracy of $\mathrm{pH}$, protein, phosphorus, and chloride measurements.

\subsubsection{Mono-, Di- and Triphosphates}

Monophosphates and the condensed phosphates di- and triphosphates were analysed by ion chromatography (IC) and conductivity detection by means of a suppressor technique, according to the method of Kaufmann and his working group [17,18]. The IC conditions were as follows: gradient elution with $50 \mathrm{mM}$ sodium carbonate and $50 \mathrm{mM}$ sodium hydrogen carbonate buffer, using the stationary phase Metrosep A Supp 5-100 (Metrohm, Filderstadt, Germany), combined with two pre-columns, Metrosep A 4/5 Guard (Metrohm) and Hypercarb $(4.6 \times 10 \mathrm{~mm}, 5 \mu \mathrm{m}$; Fisher Scientific, Schwerte, Germany). The sample preparation included heating of $5 \mathrm{~g}$ homogenised muscle tissue in $250 \mathrm{~mL}$ deionised water at $100{ }^{\circ} \mathrm{C}$ for a few minutes to stop phosphatase activity. Clarification of the extracts was achieved by centrifugation and filtration (syringe filters 0.2 or $0.45 \mu \mathrm{m}$ ), followed by injection of $10 \mu \mathrm{L}$ into the HPLC-system. The limit of detection (LOD) for di- and triphosphates is $0.01 \mathrm{~g} \cdot \mathrm{kg}^{-1}$. Recovery rates of $95.7 \%$ to $101.6 \%$ for diphosphates and $97.5 \%$ to $99.2 \%$ for triphosphates were determined by standard addition in the range of 0.5 to $2.0 \mathrm{~g} \cdot \mathrm{kg}^{-1}$ and verified the accuracy of this method.

\subsubsection{Citric Acid}

For the citric acid determination, our own laboratory procedure was developed [9]. The isocratic HPLC approach for citric acid was carried out on the column Synergi Hydro RP 80A, $4 \mu \mathrm{m}$ $(250 \times 4.6 \mathrm{~mm})$ with the pre-column AQ C18 $(4 \mathrm{~mm} \times 3.0 \mathrm{~mm})$ (both Phenomenex, Aschaffenburg, Germany), and UV detection at $220 \mathrm{~nm}$. The mobile phase, consisting of $20 \mathrm{mM}$ potassium dihydrogen phosphate, $\mathrm{pH}=2.5$, was adjusted to a flow rate of $0.4 \mathrm{~mL} \cdot \mathrm{min}^{-1}$. After preparing aqueous extracts $(100 \mathrm{~mL})$ from homogenised samples $(5 \mathrm{~g})$, Carrez I and II $(2 \mathrm{~mL}$ each) were added, and precipitated proteins were removed with a pleated filter. Before injecting into the HPLC $(20 \mu \mathrm{L})$, extracts were further purified by syringe filters $(0.2 \mu \mathrm{m})$. An LOD of $0.005 \mathrm{~g} \cdot \mathrm{kg}^{-1}$ as well as a limit of quantification (LOQ) of $0.02 \mathrm{~g} \cdot \mathrm{kg}^{-1}$ were established for citric acid. Recovery rates of $89.0 \%$ and $89.3 \%$ by standard addition of $0.5 \mathrm{~g} \cdot \mathrm{kg}^{-1}$ and $1.0 \mathrm{~g} \cdot \mathrm{kg}^{-1}$ citric acid in fish muscle tissue confirmed the accuracy of this method.

\subsubsection{Free Amino Acids, Including Taurine}

Free amino acids were determined in the perchloric acid extracts of the individual fish samples, according to a modified method of Antoine and co-workers [19].

In brief, for sample deproteinisation, $10 \mathrm{~g}$ of minced fish fillet were homogenised with $90 \mathrm{~mL}$ $6 \%$ perchloric acid $(w / w)$ and subsequently filtrated. HPLC determination of the free amino acids was performed in the diluted extracts (1:10 up to 1:500). After pre-column derivatisation with o-phthaldialdehyde (OPA) the eighteen amino acids were separated on a reversed-phase column by a solvent gradient and then quantified by fluorescence detection, using the internal standard method with 2-aminobutyric acid [20].

The LOQ was $1 \mathrm{mg} \cdot(100 \mathrm{~g})^{-1}$ fish tissue (wet weight) for each amino acid. A commercial amino acid standard for fluorescence detection (Sigma-Aldrich A 2161, Sigma-Aldrich, Merck, Darmstadt, Germany) was used as quality control. 


\subsubsection{Fatty Acid Profiles}

Fatty acid methyl esters (FAME) were obtained from $100 \mathrm{mg}$ of extracted lipids by trans-esterification with methanolic potassium hydroxide [21]. Fatty acid composition was determined, according to the German Society for Fat Science's (DGF) standard method [22].

FAME analyses were performed on a Hewlett Packard 6890 gas chromatograph (Agilent Technologies, Santa Clara, CA, USA) equipped with a split injection port, auto sampler, FID, and a $60-\mathrm{m}$ fused silica capillary column DB-23 $(60 \mathrm{~m}, 0.32 \mathrm{~mm} \times 0.25 \mu \mathrm{m}$, Agilent). Injector and detector temperatures were $250{ }^{\circ} \mathrm{C}$ and $300{ }^{\circ} \mathrm{C}$, respectively. The oven program was as follows: $140^{\circ} \mathrm{C}$ for $5 \mathrm{~min}$, to $160^{\circ} \mathrm{C}$ at $2^{\circ} \mathrm{C} \cdot \mathrm{min}^{-1}, 10 \mathrm{~min}$ isothermal, $1^{\circ} \mathrm{C} \cdot \mathrm{min}^{-1}$ to $180^{\circ} \mathrm{C}, 5 \mathrm{~min}$ isothermal, $20^{\circ} \mathrm{C} \cdot \mathrm{min}^{-1}$ to $250^{\circ} \mathrm{C}$ and finally $10 \mathrm{~min}$ isothermal. Evaluation of chromatograms was performed with an Agilent Chem-Station. Fatty acids were identified by comparison of retention times to authentic standards. The fatty acid contents in the range of 14:0 to 22:6 n-3 were shown as peak areas of all measured fatty acids (Details for calculation: [23]).

\subsubsection{Mineral Element Analysis}

Analytical details are described by [9]. In brief, $2 \mathrm{~g}$ muscle homogenate were digested in a mixture of $4 \mathrm{~mL} 65 \%$ nitric acid $(w / w)$ and $1 \mathrm{~mL} \mathrm{30 \%} \mathrm{hydrogen} \mathrm{peroxide}(w / w)$ in a closed tetrafluormethaxil quartz vessel of a temperature time programmed Milestone ultraCLAVE III digestion system (Milestone SRL, Sorisole, Italy). Sodium $(\mathrm{Na})$, potassium $(\mathrm{K})$, calcium $(\mathrm{Ca})$, magnesium $(\mathrm{Mg})$, and Zinc $(\mathrm{Zn})$ were determined by a contrAA ${ }^{\circledR} 700$ high-resolution continuum source atomic absorption spectrometer with air-acetylene flame and equipped with an auto sampler (Analytik Jena, Jena, Germany). Instrumental parameters were based on the cookbook methods for the contrAA ${ }^{\circledR} 700$ CS. Adequate calibration solutions were prepared using standard solutions (Titrisol, Merck, Darmstadt, Germany). Selenium (Se) and arsenic (As) were analysed by the continuous flow hydride system of the contrAA ${ }^{\circledR} 700$.

All samples were determined in duplicate. Blanks were digested within each run.

The commercial reference material IAEA-407 (International Atomic Energy Agency, Vienna, Austria) was used to validate the analytical methods and as quality control. Several participations in NAEL inter-laboratory comparisons on determination of the analysed elements in fish material confirmed good results. The mean values obtained for analytical recovery and the LODs were $81 \%$ and $0.09 \mathrm{mg} \cdot \mathrm{kg}^{-1}(\mathrm{Na}), 93 \%$ and $0.07 \mathrm{mg} \cdot \mathrm{kg}^{-1}(\mathrm{~K}), 89 \%$ and $0.1 \mathrm{mg} \cdot \mathrm{kg}^{-1}(\mathrm{Ca}), 87 \%$ and $0.01 \mathrm{mg} \cdot \mathrm{kg}^{-1}(\mathrm{Mg})$, $88 \%$ and $0.01 \mathrm{mg} \cdot \mathrm{kg}^{-1}(\mathrm{Se}), 87 \%$ and $0.02 \mathrm{mg} \cdot \mathrm{kg}^{-1}(\mathrm{As})$, and $89 \%$ and $0.07 \mathrm{mg} \cdot \mathrm{kg}^{-1}(\mathrm{Zn})$, respectively.

\subsection{Statistical Evaluation}

One-way ANOVA was applied for statistical analysis (SigmaStat version 3.5, Systat software Inc., San Jose, CA, USA).

\section{Results and Discussion}

\subsection{Proximate Composition, $\mathrm{pH}$ and TVB-N}

The proximate composition of all analysed turbot, barramundi and pangasius samples is shown in Tables 1-3. Muscle $\mathrm{pH}(6.4-6.9)$ and TVB-N values $\left(9.9-20.4 \mathrm{mg} \cdot(100 \mathrm{~g})^{-1}\right)$ were typical for good quality fish. The ash content of all specimens was between $0.8 \%$ and $1.3 \%$. The mean water content in the farmed fish was $\leq 80 \%$. NaCl content of untreated muscle is low [24]. Fish fillets washed with salt water can have slightly higher concentrations. Calculated from the analysed Na values, a corresponding $\mathrm{NaCl}$ content of $<0.1 \%-0.4 \%$ can be expected and was confirmed in this study with the exception of turbot from a Chilean aquaculture farm $(0.5 \% \pm 0.1 \%)$. 
Table 1. Meat composition: Mean values \pm standard deviation of turbot from four different aquaculture farms and of wild turbot (origin North-East (NE) Atlantic).

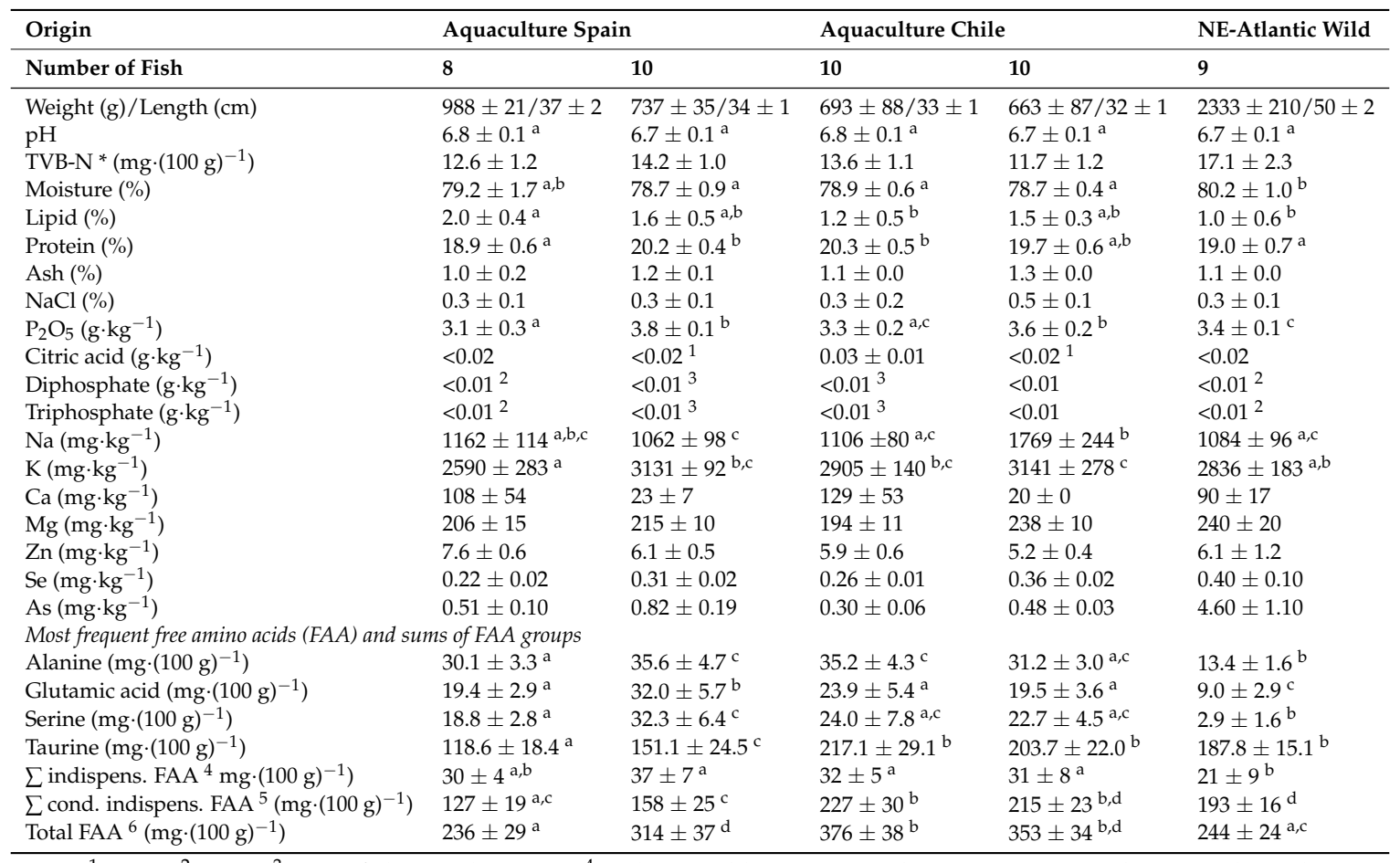

${ }^{1} n=9 ;{ }^{2} n=4 ;{ }^{3} n=5$ fish samples, resp.; ${ }^{4}$ Indispensable FAA: His, Ile, Leu, Lys, Met, Phe, Trp, Thr, Val;

${ }^{5}$ Conditionally indispens. FAA: Arg, Tau, Tyr; ${ }^{6}$ Total FAA: Ala, Asn, Asp, Glu, Gly, Ser, Orn His, Ile, Leu, Lys, Met, Phe, Trp, Thr, Val, Arg, Tau, Tyr; * Total volatile basic nitrogen. Values with different superscripts within a line are significantly different $(p<0.05)$.

Table 2. Meat composition: Mean values \pm standard deviation of farmed and wild barramundi of different origins.

\begin{tabular}{|c|c|c|c|c|}
\hline \multirow{2}{*}{ Species and Origin } & \multicolumn{2}{|c|}{ Barramundi Vietnam } & \multicolumn{2}{|c|}{ Barramundi Australia } \\
\hline & Aquaculture & Wild & Aquaculture & Wild \\
\hline Number of Samples & 10 & 4 & 10 & 10 \\
\hline $\mathrm{pH}$ & $6.9 \pm 0.1^{\mathrm{a}}$ & $6.6 \pm 0.1^{b}$ & $6.7 \pm 0.1^{b}$ & $6.4 \pm 0.1^{\mathrm{c}}$ \\
\hline TVB-N * $\left(\mathrm{mg} \cdot(100 \mathrm{~g})^{-1}\right)$ & $12.5 \pm 2.3$ & $9.9 \pm 0.5$ & $20.4 \pm 1.6$ & $17.5 \pm 1.3$ \\
\hline Moisture (\%) & $80.2 \pm 0.9^{a}$ & $79.0 \pm 0.5^{b}$ & $76.6 \pm 0.8^{b}$ & $75.7 \pm 0.8^{b}$ \\
\hline Lipid (\%) & $0.8 \pm 0.3^{\mathrm{a}}$ & $1.2 \pm 0.1^{\mathrm{a}}$ & $3.8 \pm 0.9^{b}$ & $3.2 \pm 0.7^{b}$ \\
\hline Protein $(\%)$ & $18.2 \pm 0.5^{\mathrm{a}}$ & $18.9 \pm 0.5^{\mathrm{a}}$ & $18.2 \pm 0.4^{\mathrm{a}}$ & $20.8 \pm 0.6^{b}$ \\
\hline Ash (\%) & $1.0 \pm 0$ & $0.9 \pm 0.2$ & $1.1 \pm 0.1$ & $1.1 \pm 0.1$ \\
\hline $\mathrm{NaCl}(\%)$ & $0.2 \pm 0.1$ & $0.4 \pm 0.1$ & $0.3 \pm 0.1$ & $0.2 \pm 0.1$ \\
\hline $\mathrm{P}_{2} \mathrm{O}_{5}\left(\mathrm{~g} \cdot \mathrm{kg}^{-1}\right)$ & $3.4 \pm 0.1^{\mathrm{a}}$ & $3.5 \pm 0.2^{\mathrm{a}, \mathrm{b}}$ & $4.2 \pm 0.2^{b, c}$ & $4.3 \pm 0.2^{c}$ \\
\hline Citric acid $\left(\mathrm{g} \cdot \mathrm{kg}^{-1}\right)$ & $0.19 \pm 0.06$ & $<0.02$ & $<0.02$ & $<0.005^{1}$ \\
\hline Diphosphate $\left(\mathrm{g} \cdot \mathrm{kg}^{-1}\right)$ & $<0.01$ & $<0.01$ & $<0.01$ & $<0.01$ \\
\hline Triphosphate $\left(\mathrm{g} \cdot \mathrm{kg}^{-1}\right)$ & $<0.01$ & $<0.01$ & $<0.01$ & $<0.01$ \\
\hline $\mathrm{Na}\left(\mathrm{mg} \cdot \mathrm{kg}^{-1}\right)$ & $1255 \pm 295^{\mathrm{a}}$ & $1770 \pm 79^{\mathrm{a}}$ & $633 \pm 38^{b}$ & $336 \pm 42^{c}$ \\
\hline $\mathrm{K}\left(\mathrm{mg} \cdot \mathrm{kg}^{-1}\right)$ & $2689 \pm 226^{a}$ & $2212 \pm 167^{b}$ & $3579 \pm 173^{c}$ & $3858 \pm 23^{d}$ \\
\hline $\mathrm{Ca}\left(\mathrm{mg} \cdot \mathrm{kg}^{-1}\right)$ & $273 \pm 24$ & $138 \pm 8$ & $281 \pm 89$ & $227 \pm 20$ \\
\hline $\mathrm{Mg}\left(\mathrm{mg} \cdot \mathrm{kg}^{-1}\right)$ & $237 \pm 17$ & $213 \pm 10$ & $295 \pm 26$ & $268 \pm 19$ \\
\hline $\mathrm{Zn}\left(\mathrm{mg} \cdot \mathrm{kg}^{-1}\right)$ & $4.16 \pm 0.30$ & $4.61 \pm 0.40$ & $5.51 \pm 0.38$ & $4.39 \pm 0.29$ \\
\hline $\mathrm{Se}\left(\mathrm{mg} \cdot \mathrm{kg}^{-1}\right)$ & $0.24 \pm 0.08$ & $0.29 \pm 0.08$ & $0.19 \pm 0.02$ & $0.34 \pm 0.04$ \\
\hline As $\left(\mathrm{mg} \cdot \mathrm{kg}^{-1}\right)$ & $0.70 \pm 0.64$ & $1.09 \pm 0.27$ & $0.14 \pm 0.02$ & $0.42 \pm 0.07$ \\
\hline
\end{tabular}


Table 2. Cont.

\begin{tabular}{|c|c|c|c|c|}
\hline \multirow{2}{*}{ Species and Origin } & \multicolumn{2}{|c|}{ Barramundi Vietnam } & \multicolumn{2}{|c|}{ Barramundi Australia } \\
\hline & Aquaculture & Wild & Aquaculture & Wild \\
\hline Number of Samples & 10 & 4 & 10 & 10 \\
\hline \multicolumn{5}{|c|}{ Most frequent free amino acids (FAA) and sums of FAA groups } \\
\hline Alanine $\left(\mathrm{mg} \cdot(100 \mathrm{~g})^{-1}\right)$ & $15.5 \pm 5.6^{a, b}$ & $9.8 \pm 1.0^{\mathrm{a}}$ & $28.5 \pm 3.9^{c}$ & $20.6 \pm 6.1^{b}$ \\
\hline Glutamic acid $\left.\mathrm{mg} \cdot(100 \mathrm{~g})^{-1}\right)$ & $19.0 \pm 6.6^{\mathrm{a}}$ & $10.8 \pm 1.0^{\mathrm{a}}$ & $52.3 \pm 10.2^{b}$ & $18.2 \pm 10.7^{\mathrm{a}}$ \\
\hline Glycine $\left(\mathrm{mg} \cdot(100 \mathrm{~g})^{-1}\right)$ & $33.5 \pm 36.1^{\mathrm{a}}$ & $9.5 \pm 1.7^{\mathrm{a}}$ & $274.5 \pm 26.2^{b}$ & $36.3 \pm 13.6^{\mathrm{a}}$ \\
\hline Taurine $\left(\mathrm{mg} \cdot(100 \mathrm{~g})^{-1}\right)$ & $212.5 \pm 62.4^{\mathrm{a}}$ & $169.5 \pm 3.9^{a, b}$ & $70.2 \pm 10,3^{b}$ & $262.4 \pm 44.1^{\mathrm{a}}$ \\
\hline$\sum$ indispens. FAA ${ }^{2}\left(\mathrm{mg} \cdot(100 \mathrm{~g})^{-1}\right)$ & $28 \pm 8^{a}$ & $20 \pm 1^{\mathrm{a}}$ & $33 \pm 10^{\mathrm{a}, \mathrm{b}}$ & $56 \pm 29^{b}$ \\
\hline$\sum$ cond. indispens. FAA ${ }^{3}\left(\mathrm{mg} \cdot(100 \mathrm{~g})^{-1}\right)$ & $224 \pm 62^{a, c}$ & $178 \pm 6^{\mathrm{b}, \mathrm{c}}$ & $87 \pm 13^{b}$ & $282 \pm 44^{c}$ \\
\hline Total FAA ${ }^{4}\left(\mathrm{mg} \cdot(100 \mathrm{~g})^{-1}\right)$ & $328 \pm 54^{\mathrm{a}}$ & $235 \pm 11^{b}$ & $519 \pm 54^{\mathrm{c}}$ & $430 \pm 71^{d}$ \\
\hline
\end{tabular}

${ }^{1} n=9$ fish samples; ${ }^{2}$ Indispensable FAA: His, Ile, Leu, Lys, Met, Phe, Trp, Thr, Val; ${ }^{3}$ Conditionally indispens. FAA: Arg, Tau, Tyr; ${ }^{4}$ Total FAA: Ala, Asn, Asp, Glu, Gly, Ser, Orn His, Ile, Leu, Lys, Met, Phe, Trp, Thr, Val, Arg, Tau, Tyr; ${ }^{*}$ Total volatile basic nitrogen. Values with different superscripts within a line are significantly different $(p<0.05)$.

Table 3. Meat composition: Mean values \pm standard deviation of farmed pangasius.

\begin{tabular}{|c|c|c|c|c|}
\hline \multirow[b]{2}{*}{ Number of Samples } & \multicolumn{4}{|c|}{ Pangasius, Aquaculture Vietnam } \\
\hline & \multicolumn{2}{|l|}{ Whole } & $\begin{array}{l}\text { Cutlets } \\
10\end{array}$ & $\begin{array}{l}\text { Organic Fillets } \\
10\end{array}$ \\
\hline $\mathrm{pH}$ & $6.4 \pm 0.2$ & $6.5 \pm 0.2$ & $6.6 \pm 0.1$ & $6.7 \pm 0.1$ \\
\hline TVB-N* $\left(\mathrm{mg} \cdot(100 \mathrm{~g})^{-1}\right)$ & n.d. & $12.4 \pm 1.6$ & $11.6 \pm 0.8$ & $11.3 \pm 1.1$ \\
\hline Moisture (\%) & $75.3 \pm 3.2^{\mathrm{a}}$ & $78.9 \pm 1.1^{b}$ & $78.6 \pm 1.8^{b}$ & $79.7 \pm 0.6^{b}$ \\
\hline Lipid (\%) & $7.8 \pm 3.6^{\mathrm{a}}$ & $2.7 \pm 0.9^{b}$ & $2.4 \pm 0.5^{\mathrm{b}}$ & $3.5 \pm 1.0^{\mathrm{b}}$ \\
\hline Protein (\%) & $17.2 \pm 1.6^{\mathrm{a}}$ & $18.7 \pm 1.1^{b}$ & $17.8 \pm 1.3^{b}$ & $18.1 \pm 0.5^{\mathrm{a}, \mathrm{b}}$ \\
\hline Ash (\%) & $0.8 \pm 0.1$ & $0.9 \pm 0.1$ & $0.9 \pm 0.1$ & $0.9 \pm 0.1$ \\
\hline $\mathrm{NaCl}(\%)$ & 0.1 & n.d. & 0.1 & 0.1 \\
\hline $\mathrm{P}_{2} \mathrm{O}_{5}\left(\mathrm{~g} \cdot \mathrm{kg}^{-1}\right)$ & $3.49 \pm 0.71^{\mathrm{a}}$ & $4.05 \pm 0.69^{\mathrm{a}, \mathrm{b}}$ & $4.50 \pm 1.42^{\mathrm{a}, \mathrm{b}}$ & $5.32 \pm 1.41^{b}$ \\
\hline Citric acid $\left(\mathrm{g} \cdot \mathrm{kg}^{-1}\right)$ & $<0.005$ & $<0.005$ & $<0.005$ & $<0.005$ \\
\hline Diphosphate $\left(\mathrm{g} \cdot \mathrm{kg}^{-1}\right)$ & $<0.01^{1}$ & $<0.01^{1}$ & $<0.01^{1}$ & $<0.01^{1}$ \\
\hline Triphosphate $\left(\mathrm{g} \cdot \mathrm{kg}^{-1}\right)$ & $<0.01^{1}$ & $<0.01^{1}$ & $<0.01^{1}$ & $<0.01^{1}$ \\
\hline $\mathrm{Na}\left(\mathrm{mg} \cdot \mathrm{kg}^{-1}\right)$ & $405 \pm 128^{\mathrm{a}}$ & $412 \pm 144^{\mathrm{a}}$ & $322 \pm 92^{a}$ & $389 \pm 52^{\mathrm{a}}$ \\
\hline $\mathrm{K}\left(\mathrm{mg} \cdot \mathrm{kg}^{-1}\right)$ & $3006 \pm 350^{a}$ & $3072 \pm 137^{\mathrm{a}}$ & $3003 \pm 43^{a}$ & $3132 \pm 207^{a}$ \\
\hline $\mathrm{Ca}\left(\mathrm{mg} \cdot \mathrm{kg}^{-1}\right)$ & $162 \pm 28$ & $149 \pm 21$ & $184 \pm 93$ & $127 \pm 10$ \\
\hline $\mathrm{Mg}\left(\mathrm{mg} \cdot \mathrm{kg}^{-1}\right)$ & $244 \pm 29$ & $252 \pm 23$ & $249 \pm 19$ & $254 \pm 14$ \\
\hline $\mathrm{Zn}\left(\mathrm{mg} \cdot \mathrm{kg}^{-1}\right)$ & $5.89 \pm 1.44$ & $4.95 \pm 1.01$ & $4.68 \pm 0.36$ & $3.67 \pm 0.25$ \\
\hline Se $\left(\mathrm{mg} \cdot \mathrm{kg}^{-1}\right)$ & $0.18 \pm 0.02$ & $0.18 \pm 0.01$ & $0.15 \pm 0.01$ & $0.12 \pm 0.01$ \\
\hline As $\left(\mathrm{mg} \cdot \mathrm{kg}^{-1}\right)$ & $<0.02$ & $<0.02$ & $<0.02$ & $<0.02$ \\
\hline \multicolumn{5}{|c|}{ Most frequent free amino acids (FAA) and sums of FAA groups } \\
\hline Arginine $\left(\mathrm{mg} \cdot(100 \mathrm{~g})^{-1}\right)$ & $11.9 \pm 4.4^{\mathrm{a}}$ & $13.5 \pm 6.1^{\mathrm{a}}$ & $11.1 \pm 3.5^{\mathrm{a}}$ & $8.7 \pm 1.3^{\mathrm{a}}$ \\
\hline Glycine $\left(\mathrm{mg} \cdot(100 \mathrm{~g})^{-1}\right)$ & $8.3 \pm 3.7^{\mathrm{a}}$ & $9.4 \pm 3.9^{\mathrm{a}, \mathrm{b}}$ & $14.3 \pm 4.9^{b}$ & $8.0 \pm 2.1^{\mathrm{a}}$ \\
\hline Lysine $\left(\mathrm{mg} \cdot(100 \mathrm{~g})^{-1}\right)$ & $9.8 \pm 4.9^{\mathrm{a}}$ & $11.0 \pm 6.0^{\mathrm{a}}$ & $34.8 \pm 11.2^{b}$ & $7.5 \pm 1.5^{\mathrm{a}}$ \\
\hline Taurine $\left(\mathrm{mg} \cdot(100 \mathrm{~g})^{-1}\right)$ & $88.0 \pm 27.7^{\mathrm{a}}$ & $95.5 \pm 32.0^{\mathrm{a}}$ & $99.9 \pm 9.6^{\mathrm{a}}$ & $85.9 \pm 15.3^{a}$ \\
\hline$\sum$ indispens. FAA ${ }^{2}\left(\mathrm{mg} \cdot(100 \mathrm{~g})^{-1}\right)$ & $32 \pm 8^{\mathrm{a}, \mathrm{b}}$ & $36 \pm 9^{a}$ & $68 \pm 28^{c}$ & $18 \pm 3^{b}$ \\
\hline$\sum$ cond. indispens. FAA ${ }^{3}\left(\mathrm{mg} \cdot(100 \mathrm{~g})^{-1}\right)$ & $104 \pm 25^{\mathrm{a}}$ & $114 \pm 29^{a}$ & $117 \pm 9^{a}$ & $97 \pm 16^{\mathrm{a}}$ \\
\hline Total FAA ${ }^{4}\left(\mathrm{mg} \cdot(100 \mathrm{~g})^{-1}\right)$ & $171 \pm 24^{\mathrm{a}, \mathrm{b}}$ & $186 \pm 30^{\mathrm{a}}$ & $242 \pm 46^{c}$ & $144 \pm 18^{b}$ \\
\hline
\end{tabular}

${ }^{1} n=5$ fish samples; ${ }^{2}$ Indispensable FAA: His, Ile, Leu, Lys, Met, Phe, Trp, Thr, Val ${ }^{3}$ Conditionally indispens. FAA: Arg, Tau, Tyr; ${ }^{4}$ total FAA: Ala, Asn, Asp, Glu, Gly, Ser, Orn His, Ile, Leu, Lys, Met, Phe, Trp, Thr, Val, Arg, Tau, Tyr; * Total volatile basic nitrogen. Values with different superscripts within a line are significantly different $(p<0.05) ;$ n.d. $=$ not determined .

Turbot: Wild individuals contain lipid contents near $1 \%$ which is in agreement with the results shown here in Table 1 for turbot from the North East Atlantic (1.0\%). Only slightly higher lipid contents were found in cultured turbot $(1.2 \%-2.6 \%)$, which is consistent with the results obtained by Sérot et al. [25]. Between the farmed individuals, the variation of water $(78.7-79.2, p<0.05)$ and protein $(18.9 \%-20.3 \%)$ was small. 
Barramundi: Fillets (Table 2) showed clear differences in lipid content among different origins $(p<0.05)$ with higher mean amounts in barramundi from Australia which included the belly flaps, containing higher levels compared to the tail and dorsal parts [26]. These findings are in agreement with Karl et al. [27] who also analysed low lipid content between $1.3 \%$ and $1.7 \%$ in imported frozen farmed fillets. Protein and moisture values were found to be $18.2 \%$ to $20.8 \%$ and $75.7 \%$ to $80.2 \%$, respectively, inclusive of wild specimens. The significantly higher level of $80.2 \%$ water in combination with a citric acid content of $0.188 \pm 0.060 \mathrm{~g} \cdot \mathrm{kg}^{-1}$ could not be traced back to explainable causes.

Pangasius: Frozen fillets are traded in very different qualities, indicated by low protein and high water content in the flesh, often combined with elevated $\mathrm{pH}$ values up to 8.5 (our own unpublished results) $[6,28,29]$. All analysed samples (Table 3 ) had mean moisture values $<80 \%$ and a $\mathrm{pH}<7$. The protein share ranged between $17.2 \%$ and $18.7 \%$. Water addition up to $82 \%-83 \%$ can reduce the protein content to less than $14 \%$, as estimated by Karl et al. [6]. The results also show that content and variability of moisture and lipid were distinctly $(p<0.05)$ influenced by the different skinning techniques. Pangasius flesh (edible part without belly flaps) had a mean lipid content of $7.8 \%$. Trimming and separation of the red layer by deep skinning are common practices in Vietnamese companies and reduce the lipid content of the commercially sold white-flesh fillets significantly. Values of $2.7 \%$ to $3.5 \%$ lipid for deep skinned fillets are comparable with reported data between $1 \%$ and $3 \%[6,28,30]$.

\subsection{Macro and Micro Minerals}

The dominating macro mineral element in fish tissue is $\mathrm{K}$ followed by Na. Both can vary in a large range between 2500 and $5000 \mathrm{mg} \mathrm{K} \cdot \mathrm{kg}^{-1}$ and 300-1500 mg Na. $\mathrm{kg}^{-1}$, respectively [31]. Compared to the low $\mathrm{Na}$ muscle contents in barramundi from Australia handled as whole fish (336-633 mg Na. $\mathrm{kg}^{-1}$ ), higher amounts in barramundi fillets from Vietnam were found (1255-1770 mg Na $\left.\cdot \mathrm{kg}^{-1}\right)$, confirming similar results of Karl et al. [27]. Potassium (2590-3858 mg $\cdot \mathrm{kg}^{-1}$ ) remained in its natural range. The level of $\mathrm{Mg}$ in the raw and boneless muscle is higher than that of $\mathrm{Ca}$. Summarising the results of this study, Mg ranged from 194 to $295 \mathrm{mg} \cdot \mathrm{kg}^{-1}$ which is comparable to reported data of $150-300 \mathrm{mg} \cdot \mathrm{kg}^{-1}$ for white finfish [32]. Naturally low Ca values can potentially be increased by incomplete deboning [33]. Twenty to $281 \mathrm{mg} \mathrm{Ca} \cdot \mathrm{kg}^{-1}$ were estimated. Apart biological factors a high variability caused by bone fragments is also due to phosphorus $(\mathrm{P})$. The natural occurring $\mathrm{P}$ in the flesh (estimated as $\left.\mathrm{P}_{2} \mathrm{O}_{5}\right)$ is on average $2.2 \mathrm{~g} \mathrm{~kg}^{-1}\left(\hat{=} 5.7 \mathrm{~g} \mathrm{P}_{2} \mathrm{O}_{5} \cdot \mathrm{kg}^{-1}\right)$, covering a range between 1.0 and $4.0 \mathrm{~g} \mathrm{P} \cdot \mathrm{kg}^{-1}\left(\hat{=} 2.6-10.4 \mathrm{~g} \mathrm{P}_{2} \mathrm{O}_{5} \cdot \mathrm{kg}^{-1}\right)$ [34]. For the farmed species values between 3.1 and $5.3 \mathrm{~g} \mathrm{P}_{2} \mathrm{O}_{5} \cdot \mathrm{kg}^{-1}$ were found.

As an essential micronutrient, Selenium plays a vital role in human health and is incorporated into proteins to yield selenoproteins, which are important antioxidant enzymes. Fish is an important and highly bio available source of dietary selenium [35]. Zinc, too, is essential for humans. It is the most abundant trace element. The results for Se and $\mathrm{Zn}$ cover the expected range for these elements in fish [36], except for the lower Se values for farmed Australian barramundi and pangasius.

Seafood can have naturally high levels of arsenic (As) and is known as the main contributor in the diet [37]. The EFSA [37] reported 0.1 to $1.8 \mathrm{mg} \cdot \mathrm{kg}^{-1}$ as the range for the average total arsenic concentrations in a mix of marine and freshwater fish and other seafood. Most levels found in farmed fish were in the lower or middle range. Affected by the vegetarian dominated diet, pangasius had the lowest amounts $\left(<0.02 \mathrm{mg} \cdot \mathrm{kg}^{-1}\right)$ in the muscle flesh. The sample of wild turbot contained $4.6 \mathrm{mg} \mathrm{As} \cdot \mathrm{kg}^{-1}$ and fits with the high amounts reported for body dwelling fish species [38].

\subsection{Citric Acid}

According to European legislation, food additives such as citric acid and its sodium salts are allowed without quantitative limitations (quantum satis) in frozen fish fillets with the requirement of correct labelling. There is little information in the literature about naturally occurring citric acid in aquatic animals. Chew and Ip [39] detected in the lateral muscle of mudskippers 
(Boleophthalmus boddaerti) approximately $44 \mathrm{mg}$ citric acid $\mathrm{kg}^{-1}$ and Piironen and Hyvärinen [40] found average concentrations from 5.49 to $45.13 \mathrm{mg}$ citric acid/100 mL in the seminal milt plasma of various fresh water fish like Perca fluviatilis, Salmo gairdneri, and Coregonus lavaretus. In the case of controlling correct labelling, competent authorities need reliable information about naturally occurring concentrations in fish muscle. This knowledge enables authorities to assess citric acid content in a fish fillet as a natural background, a cross-contamination or as an intentional addition to affect fish quality. In the last few years, different research groups have carried out investigations to improve the shelf life of different fish species and products with the addition of organic acids such as citric acid and/or its sodium salts used in dipping solutions [41,42] or in icing mediums [43,44]. Depending on the mentioned approaches, preliminary results of the analysis of various commercial products showed that the amount of citric acid might be low (not more than $0.1 \mathrm{~g} \cdot \mathrm{kg}^{-1}$ ) or higher up to $1 \mathrm{~g}$ or $3 \mathrm{~g} \cdot \mathrm{kg}^{-1}$.In the present study the results ranged from below the levels detectable by the analytical method (LOD $=0.005 \mathrm{~g} \cdot \mathrm{kg}^{-1}$ ) and $0.03 \mathrm{~g} \cdot \mathrm{kg}^{-1}$. However, the barramundi fillets from Vietnamese aquaculture with a concentration of $0.188 \pm 0.060 \mathrm{~g} \cdot \mathrm{kg}^{-1}$ on average seem to be an exception. Although declared as untreated, it could not be excluded that these concentrations were caused by a manipulation during filleting. The other low values for turbot, barramundi, and pangasius comply with the results of the Swiss State Laboratory of the Canton Bern $[45,46]$. Here the Swiss scientists found concentrations of citric acid lower than $0.1 \mathrm{~g} \cdot \mathrm{kg}^{-1}$ in different processed frozen fish fillets and crustaceans. They concluded that citric acid concentrations must be of natural origin, although they could not finally clarify, whether traces of citric acid were natural or from carry-over effects during production. The presented data, relating to unprocessed fish muscle tissue, confirm their assumption that only small quantities of citric acid are detectable in some fish species such as in turbot with concentrations of $>0.005 \mathrm{~g} \cdot \mathrm{kg}^{-1}$ to $0.03 \mathrm{~g} \cdot \mathrm{kg}^{-1}$ (Table 1) and as in barramundi with concentrations of $<0.02 \mathrm{~g} \cdot \mathrm{kg}^{-1}$ (Table 2 ).

\subsection{Phosphates}

Condensed phosphates could not be detected or assessed by using the photometric method for total phosphorus (Tables 1-3). Instead, IC analysis is the method of choice to control the potential addition of polyphosphates such as di- or triphosphates. Higher water content in fish fillets can often be attributed to the application of condensed phosphates due to their water binding effects. However, none of the analysed fish samples in this study contained these additives, although the barramundi fillets from Vietnam show comparably higher moisture values than barramundi from Australia.

\subsection{Fatty Acid Profile}

In turbot samples (Table 4) the fatty acid (FA) profiles within the farmed specimens were similar, but differed mainly from the wild counterparts. Apart from comparable amount of about three quarters of unsaturated FA in all samples, the percentage content of the important omega-3 polyunsaturated fatty acids (PUFA) docosahexaenoic fatty acid (C22:6n-3, DHA) and eicosapentaenoic fatty acid (C20:5n-3, EPA) was significantly higher in the fillets from wild fish $(22.6 \%, p<0.05)$. In the muscle of the wild samples, significantly lower contents for oleic acid (C18:1n-9) and linoleic acid (C18:2n-6c) and higher amounts for gondoic acid (C20:1n-9) were found $(p<0.05)$. As a result of the different feeding strategies and independent of origin, the main differences in the farmed groups were found in the content of linoleic acid (C18:2n-6c).

The fatty acid profiles of barramundi (Table 5) were characterised by high contents of saturated FA (36.9\%-43.5\%), except farmed fish from Australia (28.0\%) that had monounsaturated FA (43.6\%) nearly twice as high compared to the other specimens $(24.6 \%-25.6 \%)$. A detailed look at the wild fish showed higher contents of pentadecanoic acid (C15:0) of 4.2\% and palmitoleic acid (C16:1n-7) of 9.6\% in Australian samples compared with $0.7 \%$ and $4.6 \%$, respectively, in those from Vietnam. On the other hand, the Australian wild specimens had lower amounts of DHA with $4.1 \%$ vs. 13.3\% in those from Vietnam. Looking at the FA composition of the Australian aquaculture samples, they are characterised 
by high amounts of oleic acid (18:1n-9) and linoleic acid (C 18:2n-6). Compositions found for Vietnam aquaculture samples correspond well to findings of Karl et al. [27].

In all samples, the fatty acid composition of pangasius muscle (Table 6) was characterised by low amounts of PUFA, less than $20 \%$, and high shares of saturated and monounsaturated FA. Palmitic acid (C16:0) and oleic acid represented nearly two thirds of all analysed FA. Deep skinning did not influence the nutritional value, whereby EPA and DHA contents were both unusually high compared to the analysed cutlets and organic fillets $(p<0.05)$.

Table 4. Fatty acid (FA) composition: Mean values \pm standard deviation of turbot from four different aquaculture farms and wild turbot (origin North-East (NE) Atlantic), respectively (\% of fatty acids measured; SFA = saturated fatty acids; MUFA = monounsaturated fatty acids; PUFA = polyunsaturated fatty acids).

\begin{tabular}{|c|c|c|c|c|c|c|}
\hline \multirow{2}{*}{$\begin{array}{c}\text { Origin } \\
\text { Number of Fish }\end{array}$} & & \multicolumn{2}{|c|}{ Aquaculture Spain } & \multicolumn{2}{|c|}{ Aquaculture Chile } & \multirow{2}{*}{$\begin{array}{c}\begin{array}{c}\text { NE-Atlantic } \\
\text { Wild }\end{array} \\
9\end{array}$} \\
\hline & & 8 & 10 & 10 & 10 & \\
\hline FA Common Name & FA Shorthand & & & & & \\
\hline Myristic acid & $14: 0$ & $5.2 \pm 0.41$ & $3.8 \pm 1.00$ & $4.4 \pm 0.29$ & $4.5 \pm 0.58$ & $3.7 \pm 1.20$ \\
\hline Pentadecanoic acid & $15: 0$ & $0.4 \pm 0.02$ & $0.1 \pm 0.14$ & $0.2 \pm 0.13$ & $0.4 \pm 0.13$ & $0.5 \pm 0.08$ \\
\hline Palmitic acid & $16: 0$ & $16.7 \pm 0.89^{a}$ & $16.6 \pm 1.27^{\mathrm{a}}$ & $16.9 \pm 0.94^{\mathrm{a}}$ & $17.5 \pm 1.39^{\mathrm{a}}$ & $16.9 \pm 1.65^{\mathrm{a}}$ \\
\hline Heptadecanoic acid & $17: 0$ & $0.1 \pm 0.13$ & $0.0 \pm 0.00$ & n.d. & $0.1 \pm 0.17$ & $0.2 \pm 0.19$ \\
\hline \multirow{2}{*}{ Stearic acid } & $18: 0$ & $3.5 \pm 0.54$ & $4.3 \pm 0.89$ & $3.5 \pm 0.38$ & $4.0 \pm 0.55$ & $3.8 \pm 0.88$ \\
\hline & $\sum$ SFA & 25.8 & 24.9 & 25.0 & 26.4 & 25.2 \\
\hline Palmitoleic acid & $16: 1 n-7$ & $6.3 \pm 0.63$ & $5.2 \pm 1.36$ & $5.9 \pm 0.48$ & $5.4 \pm 0.85$ & $4.4 \pm 0.83$ \\
\hline Oleic acid & $18: 1 n-9 c$ & $12.3 \pm 0.41^{\mathrm{a}}$ & $11.6 \pm 0.93^{\mathrm{a}}$ & $11.8 \pm 0.45^{\mathrm{a}}$ & $11.5 \pm 0.78^{\mathrm{a}}$ & $9.8 \pm 0.85^{b}$ \\
\hline Vaccenic acid & $18-1 n-7$ & $3.1 \pm 0.09$ & $3.0 \pm 0.10$ & $2.9 \pm 0.06$ & $2.9 \pm 0.14$ & $2.7 \pm 0.52$ \\
\hline Gondoic acid & $20: 1 n-9$ & $1.4 \pm 0.11^{\mathrm{a}}$ & $1.1 \pm 0.30^{\mathrm{a}}$ & $1.5 \pm 0.14^{\mathrm{a}}$ & $1.4 \pm 0.13^{\mathrm{a}}$ & $3.8 \pm 1.94^{b}$ \\
\hline \multirow{2}{*}{ Erucic acid } & $22: 1 n-9$ & $0.3 \pm 0.04$ & $0.1 \pm 0.13$ & $0.2 \pm 0.10$ & $0.2 \pm 0.16$ & $0.6 \pm 0.29$ \\
\hline & $\sum$ MUFA & 23.4 & 21.0 & 22.4 & 21.4 & 21.3 \\
\hline Linoleic acid & $18: 2 n-6 c$ & $6.6 \pm 0.25^{\mathrm{a}}$ & $3.3 \pm 0.23^{b}$ & $3.8 \pm 0.12^{\mathrm{a}}$ & $6.5 \pm 0.46^{\mathrm{a}}$ & $1.5 \pm 0.28^{b}$ \\
\hline$\gamma$-Linolenic acid & $18: 3 n-6$ & $0.0 \pm 0.00$ & $0.0 \pm 0.00$ & n.d. & n.d. & $0.0 \pm 0.00$ \\
\hline$\alpha$-Linolenic acid & $18: 3 n-3$ & $0.9 \pm 0.09$ & $0.6 \pm 0.11$ & $0.7 \pm 0.05$ & $0.8 \pm 0.13$ & $0.7 \pm 0.21$ \\
\hline Stearidonic acid & $18: 4 n-3$ & $1.4 \pm 0.18$ & $1.2 \pm 0.39$ & $1.4 \pm 0.13$ & $1.1 \pm 0.23$ & $1.2 \pm 0.41$ \\
\hline Eicosadienic acid & $20: 2 n-6$ & $0.6 \pm 0.04$ & $0.2 \pm 0.13$ & $0.2 \pm 0.18$ & $0.6 \pm 0.07$ & $0.5 \pm 0.04$ \\
\hline Arachidonic acid & $20: 4 n-6$ & $1.6 \pm 0.16$ & $1.7 \pm 0.36$ & $1.7 \pm 0.28$ & $2.0 \pm 0.39$ & $2.4 \pm 0.62$ \\
\hline Eicosapentaenoic acid (EPA) & $20: 5 n-3$ & $10.8 \pm 0.45^{\mathrm{a}}$ & $12.6 \pm 0.41^{b}$ & $12.4 \pm 0.54^{b}$ & $10.1 \pm 0.67^{\mathrm{a}}$ & $6.3 \pm 0.53^{c}$ \\
\hline Docosatetraneoic acid & $22: 4 n-6$ & n.d. & $0.3 \pm 0.14$ & $0.2 \pm 0.13$ & $0.2 \pm 0.14$ & $0.4 \pm 0.25$ \\
\hline Docosapentaenoic acid (DPA) & $22: 5 n-3$ & $4.2 \pm 0.16$ & $5.1 \pm 0.40$ & $4.5 \pm 0.26$ & $4.1 \pm 0.29$ & $3.5 \pm 0.76$ \\
\hline \multirow[t]{7}{*}{ Docosahexaenoic acid (DHA) } & $22: 6 n-3$ & $13.6 \pm 1.86^{\mathrm{a}}$ & $17.6 \pm 3.37^{b}$ & $16.1 \pm 1.44^{\mathrm{a}}$ & $15.9 \pm 1.89^{\mathrm{a}}$ & $22.6 \pm 2.68^{c}$ \\
\hline & $\sum$ PUFA & 39.7 & 42.6 & 40.9 & 41.3 & 39.1 \\
\hline & unidentified & 11.1 & 11.6 & 11.7 & 11.0 & 14.4 \\
\hline & $\sum n-3$ & 30.9 & 37.1 & 35.0 & 32.0 & 34.3 \\
\hline & $\sum \mathrm{n}-6$ & 8.8 & 5.5 & 6.0 & 9.3 & 4.8 \\
\hline & Ratio n-3/n-6 & 3.5 & 6.8 & 5.9 & 3.5 & 7.1 \\
\hline & $\mathrm{EPA} \pm \mathrm{DHA}$ & 24.4 & 30.2 & 28.5 & 26.0 & 28.8 \\
\hline
\end{tabular}

n.d. = not detected; Values with different superscripts within a line are significantly different $(p<0.05)$.

Table 5. Fatty acid (FA) composition: Mean values \pm standard deviation of farmed and wild barramundi of different origins ( $\%$ of fatty acids measured; SFA = saturated fatty acids; MUFA = monounsaturated fatty acids; PUFA = polyunsaturated fatty acids).

\begin{tabular}{|c|c|c|c|c|c|}
\hline \multirow[b]{2}{*}{ Number of Samples } & \multirow[t]{2}{*}{ Species and Origin } & \multicolumn{2}{|c|}{ Barramundi Vietnam } & \multicolumn{2}{|c|}{ Barramundi Australia } \\
\hline & & Aquaculture 10 & Wild 4 & Aquaculture 10 & Wild 10 \\
\hline FA Common Name & FA Shorthand & & & & \\
\hline Myristic acid & $14: 0$ & $3.5 \pm 1.06$ & $3.5 \pm 0.62$ & $2.8 \pm 0.06$ & $4.1 \pm 0.38$ \\
\hline Pentadecanoic acid & $15: 0$ & $1.1 \pm 0.85^{\mathrm{a}}$ & $0.7 \pm 0.11^{\mathrm{a}}$ & $0.3 \pm 0.01^{\mathrm{b}}$ & $4.2 \pm 0.29^{c}$ \\
\hline Palmitic acid & $16: 0$ & $22.8 \pm 2.43^{a}$ & $26.6 \pm 1.13^{b}$ & $19.3 \pm 0.47^{\mathrm{a}}$ & $26.9 \pm 0.61^{b}$ \\
\hline Heptadecanoic acid & $17: 0$ & $1.2 \pm 0.69$ & $0.8 \pm 0.08$ & $0.3 \pm 0.10$ & $1.6 \pm 0.14$ \\
\hline \multirow[t]{2}{*}{ Stearic acid } & 18:0 & $8.3 \pm 2.61$ & $9.5 \pm 0.40$ & $5.4 \pm 0.26$ & $6.7 \pm 0.57$ \\
\hline & $\sum \mathrm{SFA}$ & 36.9 & 41.0 & 28.0 & 43.5 \\
\hline
\end{tabular}


Table 5. Cont.

\begin{tabular}{|c|c|c|c|c|c|}
\hline \multirow{2}{*}{ Number of Samples } & Species and Origin & \multicolumn{2}{|c|}{ Barramundi Vietnam } & \multicolumn{2}{|c|}{ Barramundi Australia } \\
\hline & & Aquaculture 10 & Wild 4 & Aquaculture 10 & Wild 10 \\
\hline Palmitoleic acid & $16: 1 n-7$ & $5.2 \pm 1.95^{\mathrm{a}}$ & $4.6 \pm 0.41^{b}$ & $6.6 \pm 0.14^{c}$ & $9.6 \pm 0.77^{\mathrm{d}}$ \\
\hline Oleic acid & $18: 1 n-9 c$ & $15.6 \pm 5.44^{\mathrm{a}}$ & $17.3 \pm 2.52^{\mathrm{a}}$ & $33.7 \pm 0.53^{b}$ & $12.8 \pm 0.73^{a}$ \\
\hline Vaccenic acid & $18-1 n-7$ & $3.0 \pm 0.58$ & $2.5 \pm 0.09$ & $2.6 \pm 0.04$ & $2.5 \pm 0.06$ \\
\hline \multirow[t]{2}{*}{ Gondoic acid } & $20: 1 n-9$ & $0.8 \pm 0.31^{\mathrm{a}}$ & $0.4 \pm 0.06^{b}$ & $0.6 \pm 0.03^{a, b}$ & $0.7 \pm 0.03^{\mathrm{a}}$ \\
\hline & $\sum M U F A$ & 24.6 & 24.8 & 43.6 & 25.6 \\
\hline Linoleic acid & $18: 2 n-6 c$ & $5.0 \pm 4.27^{\mathrm{a}}$ & $1.7 \pm 1.04^{b}$ & $10.9 \pm 0.16^{\mathrm{a}}$ & $1.6 \pm 0.14^{b}$ \\
\hline$\gamma$-Linolenic acid & $18: 3 n-6$ & $0.2 \pm 0.16$ & $0.0 \pm 0.00$ & $0.4 \pm 0.04$ & $0.6 \pm 0.04$ \\
\hline$\alpha$-Linolenic acid & $18: 3 n-3$ & $1.1 \pm 0.34$ & $0.5 \pm 0.08$ & $1.5 \pm 0.06$ & $1.9 \pm 0.07$ \\
\hline Stearidonic acid & $18: 4 n-3$ & $0.6 \pm 0.33$ & $0.3 \pm 0.17$ & $0.6 \pm 0.03$ & $0.8 \pm 0.07$ \\
\hline Eicosadienic acid & $20: 2 n-6$ & $0.3 \pm 0.16$ & $0.1 \pm 0.11$ & $0.1 \pm 0.09$ & $0.0 \pm 0.00$ \\
\hline Arachidonic acid & $20: 4 n-6$ & $3.3 \pm 3.55$ & $3.3 \pm 0.57$ & $0.7 \pm 0.14$ & $3.4 \pm 0.24$ \\
\hline Eicosapentaenoic acid (EPA) & $20: 5 n-3$ & $3.0 \pm 1.06^{\mathrm{a}}$ & $2.5 \pm 0.20^{b}$ & $3.0 \pm 0.11^{\mathrm{a}}$ & $3.3 \pm 0.17^{\mathrm{a}}$ \\
\hline Docosatetraneoic acid & $22: 4 n-6$ & $0.7 \pm 0.54$ & $0.8 \pm 0.30$ & $0.0 \pm 0.00$ & $0.9 \pm 0.17$ \\
\hline Docosapentaenoic acid (DPA) & $22: 5 n-3$ & $2.6 \pm 0.39$ & $2.4 \pm 0.24$ & $1.0 \pm 0.07$ & $1.8 \pm 0.15$ \\
\hline \multirow[t]{7}{*}{ Docosahexaenoic acid (DHA) } & $22: 6 n-3$ & $9.2 \pm 4.75^{\mathrm{a}}$ & $13.3 \pm 1.29^{\mathrm{a}}$ & $3.1 \pm 0.33^{b}$ & $4.1 \pm 0.31^{\mathrm{a}, \mathrm{b}}$ \\
\hline & $\sum P U F A$ & 26.0 & 25.0 & 21.2 & 18.5 \\
\hline & unidentified & 12.6 & 9.2 & 7.2 & 12.4 \\
\hline & $\sum n-3$ & 16.4 & 19.0 & 9.2 & 11.9 \\
\hline & $\bar{\sum} \mathrm{n}-6$ & 9.5 & 5.9 & 12.0 & 6.6 \\
\hline & Ratio n-3/n-6 & 1.7 & 3.2 & 0.8 & 1.8 \\
\hline & EPA + DHA & 12.2 & 15.8 & 6.2 & 7.4 \\
\hline
\end{tabular}

Values with different superscripts within a line are significantly different $(p<0.05)$.

Table 6. Fatty acid (FA) composition: Mean values \pm standard deviation of farmed pangasius ( $\%$ of fatty acids measured; SFA = saturated fatty acids; MUFA = monounsaturated fatty acids; PUFA $=$ polyunsaturated fatty acids).

\begin{tabular}{|c|c|c|c|c|c|}
\hline \multirow{3}{*}{ Number of Samples } & \multicolumn{5}{|c|}{ Pangasius, Aquaculture Vietnam } \\
\hline & & \multicolumn{2}{|l|}{ Whole } & \multirow{2}{*}{$\begin{array}{l}\text { Cutlets } \\
10 \\
\end{array}$} & \multirow{2}{*}{$\begin{array}{l}\text { Organic Fillets } \\
10\end{array}$} \\
\hline & & Skinned 10 & Deep-Skinned 10 & & \\
\hline Myristic acid & $14: 0$ & $3.7 \pm 0.89$ & $3.4 \pm 0.96$ & $4.0 \pm 0.31$ & $3.5 \pm 0.29$ \\
\hline Pentadecanoic acid & $15: 0$ & $0.4 \pm 0.23$ & $0.3 \pm 0.26$ & $0.1 \pm 0.09$ & $0.02 \pm 0.06$ \\
\hline Palmitic acid & $16: 0$ & $28.9 \pm 1.50^{\mathrm{a}, \mathrm{b}}$ & $27.9 \pm 2.16^{\mathrm{a}, \mathrm{b}}$ & $29.8 \pm 0.66^{b}$ & $27.7 \pm 0.65^{\mathrm{a}}$ \\
\hline Stearic acid & $\sum$ SFA & 43.4 & 42.2 & 42.5 & 40.3 \\
\hline Palmitoleic acid & $16: 1 n-7$ & $1.6 \pm 0.32$ & $1.5 \pm 0.25$ & $1.0 \pm 0.09$ & $0.8 \pm 0.05$ \\
\hline Oleic acid & $18: 1 n-9 c$ & $29.0 \pm 6.43^{\mathrm{a}}$ & $27.8 \pm 6.7^{\mathrm{a}}$ & $35.7 \pm 0.66^{b}$ & $31.1 \pm 0.99^{c}$ \\
\hline Vaccenic acid & $18-1 n-7$ & $1.5 \pm 0.50$ & $1.6 \pm 0.59$ & $0.8 \pm 0.06$ & $0.8 \pm 0.03$ \\
\hline \multirow[t]{2}{*}{ Gondoic acid } & $20: 1 n-9$ & $1.1 \pm 0.22^{\mathrm{a}}$ & $1.1 \pm 0.2^{\mathrm{a}}$ & $1.1 \pm 0.1^{\mathrm{a}}$ & $1.1 \pm 0.05^{\mathrm{a}}$ \\
\hline & $\sum$ MUFA & 33.3 & 32.0 & 38.7 & 33.8 \\
\hline Eicosadienic acid & $20: 2 n-6$ & $0.5 \pm 0.09$ & $0.5 \pm 0.11$ & $0.5 \pm 0.06$ & $0.8 \pm 0.07$ \\
\hline Arachidonic acid & $20: 4 n-6$ & $1.3 \pm 0.79$ & $1.9 \pm 1.02$ & $1.0 \pm 0.23$ & $1.3 \pm 0.19$ \\
\hline Eicosapentaenoic acid (EPA) & $20: 5 n-3$ & $1.2 \pm 0.79^{\mathrm{a}}$ & $1.2 \pm 0.77^{\mathrm{a}}$ & $0.1 \pm 0.09^{b}$ & $0.2 \pm 0.08^{b}$ \\
\hline Docosatetraneoic acid & $22: 4 n-6$ & $0.2 \pm 0.23$ & $0.2 \pm 0.25$ & $0.1 \pm 0.13$ & $0.2 \pm 0.17$ \\
\hline Docosapentaenoic acid (DPA) & $22: 5 n-3$ & $0.8 \pm 0.42$ & $0.8 \pm 0.41$ & $0.1 \pm 0.12$ & $0.4 \pm 0.05$ \\
\hline \multirow[t]{7}{*}{ Docosahexaenoic acid (DHA) } & $22: 6 n-3$ & $6.4 \pm 5.23^{a}$ & $7.8 \pm 5.89^{a}$ & $0.6 \pm 0.13^{b}$ & $1.4 \pm 0.19^{c}$ \\
\hline & $\sum$ PUFA & 15.3 & 17.3 & 11.7 & 18.8 \\
\hline & unidentified & 8.0 & 8.5 & 7.2 & 7.1 \\
\hline & $\sum n-3$ & 8.9 & 10.3 & 1.3 & 3.0 \\
\hline & $\sum \mathrm{n}-6$ & 6.5 & 7.0 & 10.3 & 15.7 \\
\hline & Ratio n-3/n-6 & 1.4 & 1.5 & 0.1 & 0.2 \\
\hline & $\mathrm{EPA} \pm \mathrm{DHA}$ & 7.6 & 8.9 & 0.7 & 1.6 \\
\hline
\end{tabular}




\subsection{Free Amino Acid Profile}

Amino acids are not only components of all proteins, but also precursor compounds relevant to flavour, taste, and colour of cooked foods. The contents of free amino acids (FAA) in food, especially of the indispensable and conditionally indispensable ones, are also interesting because of nutritional aspects.

Due to their osmoregulatory function, fish and other seafood usually contain more FAA than terrestrial animals. However, the total concentration of FAA in fish muscle is generally low, i.e., between $0.5 \%$ and $2 \%$, and can, additionally, be decreased during industrial processing and household preparation. Content and kind of FAA vary according to species and physiology of fish. Factors like seasonal variations, temperature, salinity, and diet influence the concentration of FAA too $[47,48]$. During the storage of fish, FAA are used by microorganisms as major substrates for growth [49].

The mean amounts of the four most frequent FAA and the sums of the indispensable, conditionally indispensable, and all analysed FAA in muscle tissue of turbot, barramundi, and pangasius are compiled in Tables 1-3. The mean total contents in the three species ranged between 144 and $519 \mathrm{mg} \cdot(100 \mathrm{~g})^{-1}$ fish fillet with pangasius showing the lowest values. All values varied more or less between single specimens within the same species. The four most frequent FAA accounts for at least $65 \%$ up to $90 \%$ of the whole FAA-pool.

With one exception, taurine was the most prevalent compound in all tested fish samples. The amino sulfonic acid taurine is of importance for various physiological processes in humans. For example, taurine is beneficial for cardiovascular health, cell membrane stabilisation, and immune defence enhancement; it reduces blood cholesterol values and has antioxidant properties [50,51]. Taurine is considered as a conditionally indispensable amino acid. During processing of fish, the content of taurine decreased mainly as a result of leaching [52].

Whereas the FAA-pool of cultured turbot tissue consisted on average of 53\% taurine, the share in the fillet of wild turbot specimens accounted for three-quarters (Table 1). Altogether, the wild turbots contained a greater percentage of indispensable and conditionally indispensable FAA than the cultured turbots.

In all tested barramundi fillets, alanine, glutamic acid, glycine and taurine were the most important FAA from a quantitative point of view (Table 2). This is consistent with a previous study [27]. However, the percentage composition of the FAA-pool was significantly different for the farmed fish coming from Vietnam and Australia. Especially the farmed Australian barramundi which contained a noticeably high amount of glycine. The low taurine content of these farmed individuals is probably due to a diet with only small amounts of sulphur containing amino acids [47]. Compared to the farmed animals, the percentage composition of FAA in wild barramundi from Vietnam and Australia are much more similar.

As expected, the deep-skinned fillet of whole pangasius contained not only more water and protein, but also a slightly higher amount of FAA than the skinned fillet of the same individual. However, the percentage composition of FAA in the two fillets corresponded (Table 3). Pangasius originating from organic aquaculture contained the lowest amount of FAA. Because of the small amounts of histidine in all fish samples, notable amounts of histamine in stored products are not expected.

\section{Conclusions}

The individual nutritional quality of farmed turbot, barramundi, and pangasius based on minerals, fatty acids, and free amino acids can be considered as comparable. Differences and variations are explainable by natural causes. However, the lipid content varied due to different feeding strategies. The main components, such as moisture and protein, seem to show only little variation in aquaculture species like barramundi and turbot and are comparable to their wild-caught counterparts. All moisture values were $\leq 80 \%$. Our results clearly show that untreated pangasius has protein values $>18 \%$, even in the case of deep-skinned fillets. 
It is not possible for foods to always contain the exact composition labelled due to natural variabilities and/or variations from production and storage conditions. Inspection authorities have to struggle with the fact that the products placed on the market are normally far away from the measurable entrance level and its basic composition. For example, most of the frozen pangasius fillets from conventional aquaculture sold on the European market are treated with water-binding additives without adequate labelling. The study shows that, in general, citric acid concentrations in unprocessed fish fillets are below under $0.1 \mathrm{~g} \cdot \mathrm{kg}^{-1}$.

Although this study is based on a limited number of samples, which may not reflect the full variation of "typical wild" or "typical cultured" fish products, it can provide basic information for fish species that are relatively new to the European market.

Acknowledgments: This work was financially supported by grants of the Department of Safety and Quality of Fruit and Vegetables of the Max Rubner-Institut. The authors thank Andreas Lopata for organizing the fish and the transport from Australia, and S. Blechner, I. Delgado, F. Grönwoldt, H.J. Knaack and A. Machetzki for their technical assistance.

Author Contributions: M. Manthey-Karl: sample collection, proximate composition and AAS, main writing; I. Lehman: fatty acids; U. Ostermeyer: amino acids; U. Schröder: citric acid/phosphates.

Conflicts of Interest: The authors declare no conflict of interest.

\section{References}

1. FAO Fisheries and Aquaculture Fact Sheets, 2015. Available online: http://www.fao.org/fishery/en (accessed on 18 May 2016).

2. Bouza, C.; Vandamme, S.; Hermida, M.; Cabaleiro, S.; Volckaert, F.; Martine, P. AquaTrace Species Leaflet: Turbot (Scophthalmus maximus), 2014. Available online: https:/ /aquatrace.eu/web/aquatrace/leaflets/turbot (accessed on 18 May 2016).

3. FAO. Cultured Aquatic Species Information Program. Psetta Maxima, 2016. Available online: http://www. fao.org/fishery/culturedspecies/Psetta_maxima/en (accessed on 18 May 2016).

4. Russell, D.J.; Garrett, R.N. Early life history of barramundi, Lates calciferer (Bloch) in North Eastern Queenslan. Aust. J. Mar. Freshw. Res. 1985, 36, 191-201.

5. Hilge, V. Untersuchungen zur Aufzucht von Barramundi. Inf. Fischwirtsch. Fischereiforsch. 2003, 50, $22-23$.

6. Karl, H.; Lehmann, I.; Rehbein, H.; Schubring, R. Composition and quality attributes of conventionally and organically farmed Pangasius fillets (Pangasius hypophthalmus) on the German market. Int. J. Food Sci. Technol. 2010, 45, 56-66. [CrossRef]

7. Institut für Hygiene und Umwelt. Jahresbericht 2013 des Hamburger Instituts für Hygiene und Umwelt. Available online: http:/ /www.hamburg.de/contentblob/4392204/data/hu-jahresbericht-2013.pdf (accessed on 18 May 2016). (In German)

8. Guimarães, C.F.M.; Mársico, E.T.; Guerra Monteiro, M.L.; Lemos, M.; Mano, S.B.; Conte Junior, C.A. The chemical quality of frozen Vietnamese pangasius hypophthalmus fillets. Food Sci. Nutr. 2016, 4, 398-408. [CrossRef] [PubMed]

9. Manthey-Karl, M.; Lehmann, I.; Ostermeyer, U.; Rehbein, H.; Schröder, U. Meat composition and quality assessment of king scallops (Pecten maximus) and frozen Atlantic sea scallops (Placopecten magellanicus) on a retail level. Foods 2015, 4, 524-546. [CrossRef]

10. Antonacopoulos, N. Untersuchungsverfahren (Sensorik, Chemie). In Fische und Fischerzeugnisse, 2nd ed.; Ludorff, W., Meyer, V., Eds.; Paul Parey: Berlin/Hamburg, Germany, 1973; p. 219.

11. AOAC Method \#968.06. Official Methods of Analysis of AOAC International, 18th ed.; AOAC International: Gaithersburg, MD, USA, 2005.

12. Smedes, F. Determination of total lipid using non-chlorinated solvents. Analyst 1999, 124, 1711-1718. [CrossRef]

13. Karl, H.; Bekaert, K.; Berge, J.-P.; Cadun, A.; Duflos, G.; Oehlenschläger, J.; Poli, B.M.; Tejada, M.; Testi, S.; Timm-Heinrich, M. WEFTA interlaboratory comparison on total lipid determination in fishery products using the Smedes method. J. AOAC Int. 2012, 95, 1-5. [CrossRef] 
14. Karl, H.; Äkesson, G.; Etienne, M.; Huidobro, A.; Luten, J.; Mendes, R.; Tejada, M.; Oehlenschläger, J. WEFTA interlaboratory comparison on salt determination in fishery products. J. Aquat. Food Prod. Technol. 2002, 11, 215-228. [CrossRef]

15. LFGB. Bestimmung des Gesamtphosphorgehaltes in Fleisch und Fleischerzeugnissen. Photometrisches Verfahren. L06.00-9. In Amtliche Sammlung von Untersuchungsverfahren Nach § 64 LFGB; Beuth-Verlag: Berlin, Germany, 2008.

16. EU Commission. Commission Regulation (EC) No. 2074/2005 of 5 December 2005 Laying down Implementing Measures for Certain Products under Regulation (EC) No. 853/2004 of the European Parliament and of the Council and for the Organisation of Official Controls under Regulation (EC) No. 854/2004 of the European Parliament and of the Council and Regulation (EC) No. 882/2004 of the European Parliament and of the Council, Derogating from Regulation (EC) No. 852/2004 of the European Parliament and of the Council and Amending Regulations (EC) No. 853/2004 and (EC) No. 854/2004. Available online: http:/ / eur-lex.europa.eu/legal-content/EN/ALL/?uri=CELEX:32005R2074 (accessed on 18 May 2016).

17. Kaufmann, A.; Pacciarelli, B. Determination of some ionic additives in meat products by ion chromatography. Mitt. Gebiete Hyg. 2000, 91, 581-596.

18. Kaufmann, A.; Maden, K.; Leisser, W.; Mater, M.; Gude, T. Analysis of polyphosphates in fish and shrimps tissues by two different ion chromatography methods: Implications on false-negative and -positive findings. Food Addit. Contam. 2005, 22, 1073-1082. [CrossRef] [PubMed]

19. Antoine, F.R.; Wei, C.I.; Littell, R.C.; Marshall, M.R. HPLC Method for analysis of free amino acids in fish using o-phthaldialdehyde precolumn derivatization. J. Agric. Food Chem. 1999, 47, 5100-5107. [CrossRef] [PubMed]

20. Manthey-Karl, M.; Ostermeyer, U.; Barth, J.; Rehbein, H. Quality aspects and species identification of cephalopod products on the German market. Arch. Lebensmhyg. 2013, 64, 15-23.

21. DGF (Deutsche Gesellschaft für Fettwissenschaft, German Society for Fat Science). DGF-Einheitsmethode C-VI-11d. Fettsäuremethylester (Alkalische Umesterung); Wissenschaftliche Verlagsgesellschaft mbH: Stuttgart, Germany, 1998.

22. DGF (Deutsche Gesellschaft für Fettwissenschaft, German Society for Fat Science). DGF-Einheitsmethode C-VI-10a. Gaschromatographie: Analyse der Fettsäuren und Fettsäureverteilung; Wissenschaftliche Verlagsgesellschaft mbH: Stuttgart, Germany, 2000.

23. Ostermeyer, U.; Molkentin, J.; Lehmann, I.; Rehbein, H.; Walte, H.G. Suitability of instrumental analysis for the discrimination between wild-caught and conventionally and organically farmed shrimps. Eur. Food Res. Technol. 2014, 239, 1015-1029. [CrossRef]

24. Suttle, N.F. Mineral Nutrition of Livestock, 4th ed.; CAB International: Wallingford, UK, 2010.

25. Sérot, T.; Gandemer, G.; Demaimay, M. Lipid and fatty acid compositions of muscle from farmed and wild adult turbot. Aquacult. Int. 1998, 6, 331-343. [CrossRef]

26. Percival, S.; Drabsch, P.; Glencross, B. Determing factors affecting muddy-flavour taint in farmed barramundi, Lates calcarifier. Aquaculture 2008, 284, 136-143. [CrossRef]

27. Karl, H.; Lehmann, I.; Manthey-Karl, M.; Meyer, C.; Ostermeyer, U. Comparison of nutritional value and microbiological status of new imported fish species on the German market. Int. J. Food Sci. Technol. 2014, 49, 2481-2490. [CrossRef]

28. Orban, E.; Nevigato, T.; Lena, G.; Masci, M.; Casini, I.; Gambelli, L.; Caproni, R. New trends in the seafood market. Sutchi catfish (Pangasius hypophthalmus) fillets from Vietnam: Nutritional quality and safety aspects. Food Chem. 2008, 110, 383-389. [CrossRef] [PubMed]

29. Van Ruth, S.M.; Brouwer, E.; Koot, A.; Wijtten, M. Seafood and Water Management. Foods 2014, 3, 622-631. [CrossRef]

30. Polak-Juszczak, L. Chemical characteristics of fishes new to the polish market. Acta Sci. Pol. 2007, 6, $23-32$.

31. Causeret, J. Fish as source of mineral nutrition. In Fish as Food. Nutrition, Sanitation and Utilization, Vol. 2; Bergstrom, G., Ed.; Academic Press: Orlando, FL, USA, 1962; pp. 205-228.

32. Allen, L.; Prentice, A. Encyclopedia of Human Nutrition; Academic Press: Oxford, UK, 2005.

33. Holland, B.; Brown, J.; Buss, D.H. Fish and Fish Products, Third Supplement to the Fifth Edition of McCance and Widdowson's "The Composition of Foods"; The Royal Society of Chemistry: Cambridge, UK, 1993.

34. USDA. Finfish and Shellfish Products. Available online: http://naldc.nal.usda.gov/naldc/download.xhtml? id=CAT87886653\&content=PDF (accessed on 18 May 2016). 
35. Schram, E.; Pedrero, Z.; Cámara, C.; van der Heul, J.W.; Luten, J.B. Enrichment of African catfish with functional selenium originating from garlic. Aquacult. Res. 2008, 39, 850-860. [CrossRef]

36. FCT. The Norwegian Food Composition Table, 2015. Available online: http://www.matportalen.no/ verktoy/the_norwegian_food_composition_table/ (accessed on 18 May 2016).

37. EFSA. EFSA Panel on Contaminants in the Food Chain. Scientific Opinion on Arsenic in Food. EFSA J. $2009,7$. [CrossRef]

38. Sirot, V.; Guérin, T.; Volatier, J.L.; Leblanc, J.C. Dietary exposure and biomarkers of arsenic in consumers of fish and shellfish from France. Sci. Total Environ. 2009, 407, 1875-1885. [CrossRef] [PubMed]

39. Chew, S.F.; Ip, Y.K. Biochemical adaptions of the mudskipper Boleophthalmus boddaerti to a lack of oxygen. Mar. Biol. 1992, 112, 567-571. [CrossRef]

40. Piironen, J.; Hyvärinen, H. Composition of the milt of some teleost fishes. J. Fish. Biol. 1983, 22, 351-361. [CrossRef]

41. Aubourg, S.P.; Pérez-Alonso, F.; Gallardo, J.M. Studies on rancidity inhibition in frozen horse mackerel (Trachurus trachurus) by citric and ascorbic acids. Eur. J. Lipid Sci. Technol. 2004, 106, 232-240. [CrossRef]

42. Sallam, K.I. Chemical, sensory and shelf life evaluation of sliced salmon treated with salts of organic acids. Food Chem. 2007, 101, 592-600. [CrossRef] [PubMed]

43. Sanjuás-Rey, M.; García-Soto, B.; Barros-Velázquez, J.; Fuertes-Gamundi, J.R.; Aubourg, S.P. Effect of a two-step natural organic acid treatment on microbial activity and lipid damage during blue whiting (Micromesistius poutassou) chilling. Int. J. Food Sci. Technol. 2011, 46, 1021-1030. [CrossRef]

44. García-Soto, B.; Fernández-No, I.C.; Barros-Velázquez, J.; Aubourg, S.P. Use of citric and lactic acids in ice to enhance quality of two fish species during on-board chilled storage. Int. J. Refrig. 2014, 40, 390-397. [CrossRef]

45. Kantonales Laboratorium Bern (Swiss State Laboratory of the Canton Bern). Jahresbericht 2005; Annual Report; Kantonales Laboratorium: Bern, Switzerland, 2005. (In German)

46. Kantonales Laboratorium Bern (Swiss State Laboratory of the Canton Bern). Jahresbericht 2006; Annual Report; Kantonales Laboratorium: Bern, Switzerland, 2006. (In German)

47. Luten, J.; Schram, E.; Elvevoll, E. Tailor-made functional seafood for consumers: Dietary modulation of selenium and taurine in farmed fish. In Improving Farmed Fish Quality and Safety; Lie, Ø., Ed.; CRC Press: Boca Raton, FL, USA, 2008; pp. 343-362.

48. Ruiz-Capillas, C.; Jiménez-Colmenero, F. Biogenic Amines in Seafood Products. In Handbook of Seafood and Seafood Products Analysis; Nollet, L.M.L., Toldra, F., Eds.; CRC Press: Boca Raton, FL, USA, 2010; pp. 833-850.

49. Yassoralipour, A.; Bakar, J.; Rahmann, R.A.; Bakar, F.A.; Golkhandan, E. Effect of different temperatures on the free amino acids, physico-chemical and microbial changes during storage of barramundi (Lates calcarifer) fillets. Adv. J. Food Sci. Technol. 2013, 5, 822-828.

50. Undeland, I. Selected amino acids in fish. In Marine Functional Food; Luten, J.B., Ed.; Academic Publishers: Wageningen, The Netherlands, 2009; pp. 43-47.

51. Ferraro, V.; Cruz, I.; Jorge, R.F.; Malcata, F.X.; Pintado, M.E.; Castro, P.M.L. Valorisation of natural extracts from marine source focused on marine by-products: A review. Food Res. Intern. 2010, 43, 2221-2233. [CrossRef]

52. Dragnes, B.T.; Larsen, R.; Ernstsen, M.H.; Mæhre, H.; Elvevoll, E.O. Impact of processing on the taurine content in processed seafood and their corresponding unprocessed raw materials. Intern. J. Food Sci. Nutr. 2009, 60, 143-152. [CrossRef] [PubMed]

(C) 2016 by the authors; licensee MDPI, Basel, Switzerland. This article is an open access article distributed under the terms and conditions of the Creative Commons Attribution (CC-BY) license (http://creativecommons.org/licenses/by/4.0/). 